\title{
PENGARUH SUHU VULKANISASI TERHADAP SIFAT MEKANIS VULKANISAT KARET ALAM DAN KARET AKRILONITRIL-BUTADIENA
}

\section{EFFECT OF VULCANIZATION TEMPERATURE ON THE MECHANICAL PROPERTIES OF VULCANIZED NATURAL AND ACRYLONITRILE-BUTADIENE RUBBERS}

\author{
Norma Arisati Kinasih*, Mohamad Irfan Fathurrohman, Dadang Suparto \\ Pusat Penelitian Karet, Jalan Salak No. 1 Bogor 16151, Indonesia \\ *Penulis korespondensi. Tel.: +62251 831 9817, Fax.:+62251 8324047 \\ E-mail: norma.kinasih88@gmail.com
}

Diterima: 14 Agustus 2015 Direvisi: 13 Oktober 2015 Disetujui: 16 Oktober 2015

\begin{abstract}
Natural and acrylonitrile-butadiene rubbers possess different vulcanization characteristics. Selection of the vulcanization system and temperature affects the mechanical properties of vulcanized natural rubber (NR) and acrylonitrile-butadiene rubber (NBR). In the present work, the effect of vulcanization temperature (150, 160, 170 and $180^{\circ} \mathrm{C}$ ) on the mechanical properties of $N R$ and NBR vulcanizates was studied. The effect of different vulcanization system (semi efficient, efficient and sulfur donor) was studied in NR blends, while the effect of different acrylonitrile content (26, 28 and $33 \mathrm{wt} \%$ ) was studied in NBR blends. The NBR curing characteristics and mechanical properties data showed that vulcanization at low temperature $\left(150^{\circ} \mathrm{C}\right)$ was suitable for low acrylonitrile-NBR, whereas that at high temperature $\left(170^{\circ} \mathrm{C}\right)$ was suitable for high acrylonitrile-NBR. In addition, the semi efficient system at low temperature vulcanization $\left(150^{\circ} \mathrm{C}\right)$ was suitable for natural rubber.
\end{abstract}

Keywords: vulcanization temperature, acrylonitrile, NBR, natural rubber, mechanical properties.

\begin{abstract}
ABSTRAK
Karet alam dan karet akrilonitril-butadiena memiliki karakteristik vulkanisasi yang berbeda. Pemilihan sistem dan suhu vulkanisasi berpengaruh terhadap sifat mekanis vulkanisat karet alam (NR) dan karet akrilonitril-butadiena (NBR). Pada penelitian ini dipelajari pengaruh suhu vulkanisasi $\left(150,160,170\right.$, dan $\left.180^{\circ} \mathrm{C}\right)$ terhadap sifat mekanis vulkanisat NR dan NBR. Pada NR dipelajari pengaruh sistem vulkanisasi yang berbeda (semi efisien, efisien dan donor sulfur), sedangkan pada NBR lebih difokuskan terhadap pengaruh kandungan akrilonitril yang berbeda (26, 28, dan 33\% b/b). Karakteristik pematangan dan sifat mekanis karet NBR menunjukkan bahwa karet NBR dengan kandungan akrilonitril yang rendah lebih sesuai divulkanisasi pada suhu rendah $\left(150^{\circ} \mathrm{C}\right)$, sedangkan karet NBR dengan kandungan akrilonitril yang tinggi lebih sesuai divulkanisasi pada suhu tinggi $\left(170^{\circ} \mathrm{C}\right)$. Vulkanisat karet alam lebih sesuai divulkanisasi menggunakan sistem vulkanisasi semi efisien dengan suhu vulkanisasi sebesar $150^{\circ} \mathrm{C}$.
\end{abstract}

Kata kunci: suhu vulkanisasi, akrilonitril, NBR, karet alam, sifat mekanis.

\section{PENDAHULUAN}

Suatu industri salalu berusaha menurunkan biaya produksinya tanpa mengurangi kualitas produknya, tidak terkecuali pada industri karet. Kualitas produk karet ditentukan oleh beberapa hal seperti: jenis karet, jumlah dan jenis bahan kimia, sistem produksi dan vulkansisasi, dan desain produk. Peningkatan kualitas produk karet dapat dilakukan dengan mengkaji faktor-faktor tersebut, salah satunya vulkanisasi (Palaty \& Joseph, 2001). Vulkanisasi merupakan suatu proses perubahan sifat karet dari termoplastik menjadi 
thermoset untuk meningkatkan sifat elastis, struktur molekul karet membentuk jaringan tiga dimensi yang disebut ikatan silang (Hofmann, 1965).

Sistem vulkanisasi belerang merupakan sistem vulkanisasi yang umumnya digunakan pada pembuatan barang jadi karet. Terdapat tiga sistem vulkanisasi belerang yaitu: sistem konvensional (CV), sistem efisien (EV), dan sistem semiefisien (SEV), ketiganya dibedakan berdasarkan perbandingan konsentrasi belerang dengan pencepat (Long, 1985). Komposisi tersebut menghasilkan komposisi ikatan silang jenis monosulfida, disulfida, dan polisulfida yang berbeda, sehingga menghasilkan sifat mekanis dan dinamis produk karet yang berbeda pula (Pal et al.,1981; Fan et al., 2001; Gonzalez et al., 2002). Suhu vulkanisasi turut berperan dalam menentukan sifat mekanis dan dinamis vulkanisat karet (Blokh, 1972; Fan et al., 2001; Zhang et al., 2015). Vulkanisasi pada suhu yang tinggi dapat mempercepat waktu vulkanisasi, sehingga dapat menurunkan biaya produksi. Namun, vulkanisasi pada suhu tinggi menyebabkan tidak terkontrolnya reaksi samping sehingga menurunkan kualitas produk (Fan et al., 2001; Basfar et al., 2002; Zhang et al., 2015). Sedangkan pada suhu rendah menghasilkan kualitas dan penampakan produk karet alam dan sintetis yang lebih baik dibandingkan suhu tinggi (Chasar \& Layer, 1996; Palaty, 2002; Palaty \& Joseph, 2006). Namun, membutuhkan waktu vulkanisasi yang lama sehingga meningkatkan biaya produksi.

Karet alam dan sintetis memiliki karakteristik sistem vulkanisasi yang berbeda. Dibandingkan dengan karet alam, karet sintetis divulkanisasi menggunakan bahan pencepat yang lebih banyak dibanding sulfur untuk menghasilkan kualitas vulkanisat yang baik (Palaty \& Joseph, 2006; ElNemr, 2011). Pada karet akrilonitril-butadiena (NBR) (kandungan akrilonitri 34\%), peningkatan suhu vulkanisasi dapat meningkatkan pampat tetap, ketahanan abrasi, ketahanan patah (crack) dan modulus, dan menurunkan kekerasan, kuat tarik dan ketahanan sobek (Bhowmick \& De, 1979). Sedangkan Palaty \& Joseph (2006) melaporkan bahwa ketika NBR (kandungan akrilonitril 33\%) divulkanisisasi pada suhu vulkanisasi $\left(60-150^{\circ} \mathrm{C}\right)$ dengan variasi komposisi pengaktif dan pencepat berbeda menunjukkan bahwa kuat tarik, ketahanan sobek, dan jumlah ikatan silang menurun, sedangkan perpanjangan putus, abrasi, dan pampat tetap meningkat seiring kenaikan suhu vulkanisasi. Pada karet alam (NR) yang divulkanisasi dengan sistem CV, SEV, dan EV menunjukkan bahwa peningkatan suhu vulkanisasi (150$180^{\circ} \mathrm{C}$ ) mempercepat waktu pemasakan optimum $\left(\mathrm{t}_{90}\right)$ dan reversi, menurunkan kuat tarik, kekerasan, modulus, ketahanan sobek, pampat tetap (Mukhopadhyay et al., 1977; Fan et al., 2001) dan sifat dinamisnya (Fan et al., 2001). Hasil sebalikya dilaporkan Zhang et al. (2015), karet alam yang divulkanisasi dengan suhu tinggi $\left(150-180^{\circ} \mathrm{C}\right)$ menggunakan sistem SEV menunjukkan peningkatan sifat pampat tetap, perpanjangan putus, dan heat buildup, namun terjadi penurunan kuat tarik, kekerasan, modulus dan resilience.

Pemilihan sistem dan suhu vulkanisasi sangat menentukan karakteristik NR dan NBR guna memenuhi standar mutu produk-produk karet yang spesifik. Berdasarkan penelitian terdahulu, yang telah dijabarkan di atas diketahui bahwa masih terdapat minimnya informasi mengenai pengaruh kandungan akrilonitril NBR dan suhu vulkanisasi terhadap sifat vulkanisat karet NBR. Selain itu, pengaruh suhu terhadap sistem vulkanisasi selain sulfur di NR seperti donor sulfur, masih memerlukan kajian. Maka pada penelitian ini akan dipelajari pengaruh suhu vulkanisasi terhadap sifat mekanis karet alam dan NBR. Pada NR, dipelajari pengaruh sistem (EV, SEV, dan donor sulfur) dan suhu vulkanisasi, sedangkan pada karet NBR lebih difokuskan terhadap pengaruh kandungan akrilonitril dan suhu vulkanisasi terhadap sifat mekanis vulkanisat karet NBR. Penelitian ini dipandang perlu dilakukan guna memberikan pengetahuan bagi pelaku usaha industri karet yang menggunakan NR dan NBR sebagai bahan bakunya agar dapat meningkatkan mutu produk dan menurunkan biaya produksinya.

\section{BAHAN DAN METODE \\ Bahan Penelitian}

Bahan penelitian yang digunakan utuk pembuatan kompon terdiri atas karet NBR jenis Krynac 2645, 2845, dan 3345 Ex. Laxees dan Perbunan, karet alam jenis crepe (lateks diperoleh dari kebun percobaan Ciomas, Bogor), Fast Extrusion Furnance (FEF) Black Ex. Cabot, anti ozon (Antilux) Ex. Rhei Chemie, 2,2,4-trimethyl-1,2-dihydroquinoline (TMQ) Ex. Kemai, asam stearat (Aktiplas T60) Ex.Rhei Chemie, tetrametiltiuram disulfida (TMTD) Ex. Stair Chem, n-pentana Ex. Merck, dioktil ftalat (DOP), seng oksida ( $\mathrm{ZnO}), \mathrm{N}$-cyclohexyl-2-benzothiazolesulfenamide (CBS), $N$-tert- 
butyl-2-Benzothiazolesulfenamide (TBBS), 2,2'dibenzothiazyl disulfide (MBTS), 4,4'-dithiodimorpholine (DTDM) dan sulfur diperoleh dari penyuplai lokal.

\section{Peralatan Penelitian}

Peralatan yang digunakan pada penelitian ini meliputi open mill - Berstorf, Moving Die Rheometer (MDR 2000), mesin pres (Hirara \& Co Ltd), Shore durometer hardness tester dan tensometer (Loyd 2000R).

\section{Metode Penelitian}

\section{Pembuatan vulkanisat}

Vulkanisat karet NBR dibuat dengan menggunakan tiga jenis karet NBR yang ada di pasaran dengan kandungan akrilonitril yang berbeda yaitu NBR 2645 (26\% b/b akrilonitril), NBR 2845 (28\% b/b akrilonitril), dan NBR 3345 (33\% b/b akrilonitril). Sedangkan komposisi kompon NR dibedakan berdasarkan sistem vulkanisasinya; sistem semi efisien (NRSEV), sistem efisien (NREV) dan menggunakan donor sulfur (NRDonor). Komposisi keenam kompon tersebut disajikan pada Tabel 1.

Keenam kompon tersebut digiling terpisah menggunakan mesin giling terbuka. Kompon ka- ret NBR digiling tanpa diawali proses mastikasi, sedangkan kompon karet alam diawali dengan proses mastikasi terlebih dahulu. Kompon karet tersebut selanjutnya disimpan pada suhu ruang selama 24 jam sebelum divulkanisasi. Ketiga kompon karet NBR tersebut dimasak dengan sistem vulkanisasi efisien, sedangkan kompon karet alam divulkanisasi dengan sistem SEV, EV dan donor sulfur dengan variasi suhu 150, 160, 170, dan $180^{\circ} \mathrm{C}$.

\section{Karakterisasi pematangan}

Masing-masing kompon tersebut diuji karakteristik pematangannya menggunakan rheometer pada suhu $150,160,170$ dan $180^{\circ} \mathrm{C}$, yang meliputi; torsi maksimum $\left(M_{\mathrm{H}}\right)$ dan minimum $\left(M_{\mathrm{L}}\right)$, delta torsi $\left(M_{\mathrm{H}}-M_{\mathrm{L}}\right)$ dan waktu optimum vulkanisasi $\left(\mathrm{t}_{90}\right)$. Ketahanan karet terhadap suhu tinggi didefinisikan sebagai $R_{300}$. $R_{300}$ adalah persentase nilai penurunan torsi setelah torsi maksimum (reversion resistant) dihitung berdasarkan persamaan (1) berikut (Khang \& Ariff, 2012).

$R_{300}=\frac{M_{\mathrm{H}}-M_{300 \mathrm{~s}}}{M_{\mathrm{H}}} \times M_{\mathrm{H}}$

$\mathrm{M}_{300 \mathrm{~s}}$ adalah torsi setelah 300 detik dari torsi maksimum.

Tabel 1. Desain kompon karet NBR.

\begin{tabular}{lcccccc}
\hline \multirow{2}{*}{ Bahan } & \multicolumn{5}{c}{ Kompon (phr*) } \\
\cline { 2 - 6 } & NBR26 & NBR28 & NBR33 & NRSEV & NREV & NRDonor \\
\hline NBR 2645 & 100 & & & & & \\
NBR 2845 & & 100 & & & 100 & 100 \\
NBR 3345 & & & 100 & & 0,5 & \\
NR & 0,3 & 0,3 & 0,3 & 1,3 & & 1,5 \\
Sulfur & & & & & 50 & 50 \\
DTDM & 10 & 10 & 10 & 50 & 2 & 2 \\
N550 & 2 & 2 & 2 & 2 & 1 & 1 \\
Antilux & 1 & 1 & 1 & 1 & 5 & 5 \\
TMQ & 5 & 5 & 5 & 5 & 5 & 5 \\
DOP & 5 & 5 & 5 & 5 & 2 & 2 \\
ZnO & 1 & 1 & 1 & 2 & & 1,5 \\
Asam stearat & 1,5 & 1,5 & 1,5 & & & \\
CBS & 2,5 & 2,5 & 2,5 & & & \\
TMTD & & & & 1,2 & 2,5 & 2,5 \\
TBBS & & & & 0,3 & 0,5 & 0,5 \\
MBTS & & & & & & \\
\hline
\end{tabular}

* part per hundred rubber 


\section{Pengujian sifat mekanis vulkanisat}

Kompon NR dan NBR divulkanisasi menggunakan mesin press pada variasi suhu 150, 160, 170 dan $180^{\circ} \mathrm{C}$ dengan tekanan sebesar $100 \mathrm{~kg} /$ $\mathrm{cm}^{2}$. Lama waktu pemasakan masing-masing kompon disesuaikan dengan waktu pemasakan optimum $\left(\mathrm{t}_{90}\right)$ hasil pengujian rheometer. Vulkanisat dicetak membentuk lembaran persegi $(15 \times 15 \mathrm{~cm})$ setebal $2 \mathrm{~mm}$ untuk preparasi pengujian sifat mekanis vulkanisat, sedangkan untuk pengujian pampat tetap, sampel dicetak dengan bentuk silinder dengan diameter $12 \mathrm{~mm}$ dan tebal $6 \pm 0,2 \mathrm{~mm}$. Vulkanisat kemudian diuji sifat mekanis yang meliputi; kekerasan, kuat tarik, perpanjangan putus dan pampat tetap 72 jam pada suhu $27 \pm 2^{\circ} \mathrm{C}$. Metode uji sifat mekanis vulkanisat mengacu pada SNI 7655:2010.

\section{HASIL DAN PEMBAHASAN}

\section{Karakteristik Pematangan Karet NBR}

Karakteristik pematangan keempat kompon NBR (Tabel 2) sangat dipengaruhi oleh suhu pematangan dan kandungan akrilonitril karet NBR. Peningkatan suhu vulkanisasi menyebabkan sedikit penurunan torsi maksimum dari semua kompon NBR. Torsi maksimum $\left(M_{\mathrm{H}}\right)$ merepresentasikan ikatan silang maksimum yang terbentuk selama vulkanisasi (Indrajati \& Sholeh, 2014). Kompon NBR dengan kandungan akrilonitril rendah $(26 \% \mathrm{~b} / \mathrm{b}$ dan $28 \% \mathrm{~b} / \mathrm{b})$ menghasil- kan torsi maksimum yang lebih besar dibandingkan kompon NBR dengan kandungan akrilonitril tinggi $(33 \% \mathrm{~b} / \mathrm{b})$. Hal ini menunjukkan bahwa pada kompon NBR 26 dan NBR 28 menghasilkan jumlah ikatan silang yang lebih banyak dibanding kompon NBR 33. Torsi minimum $\left(M_{\mathrm{L}}\right)$ merupakan indikator viskositas kompon (Konar \& Saha, 2012; Marković et al., 2013; Indra et al., 2013) serta memberikan informasi terkait kemampuan proses dari kompon (Nabil et al., 2013). Pada Tabel 2 terlihat bahwa nilai torsi minimum dari semua kompon NBR relatif sama, viskositas kompon NBR relatif sama disebabkan semua bahan baku NBR yang digunakan pada penelitian ini memiliki viskositas Mooney yang sama, yaitu 45 unit Mooney. Peningkatan suhu relatif meningkatkan torsi minimum, hal ini dimungkinkan karena pada sistem vulkanisasi ini menggunakan bahan pencepat sulfanemida (CBS dan TMTD) sehingga memungkinkan terjadinya reaksi ikatan silang yang lebih awal. Delta torsi secara tidak langsung terkait dengan kerapatan ikatan silang total dari sebuah kompon (Gonzalez et al., 2005; 2008; Nabil et al., 2013a; Indra et al., 2013). Tabel 2 menunjukkan bahwa delta torsi sedikit menurun dengan peningkatan suhu vulkanisasi. Delta torsi kompon NBR 26 dan NBR 28 cenderung lebih besar dibanding delta torsi kompon NBR33.

Optimum curing time $\left(\mathrm{t}_{90}\right)$ karet NBR menurun seiring kenaikan suhu vulkanisasi pada setiap

Tabel 2. Karakteristik pematangan kompon karet NBR.

\begin{tabular}{lcccc}
\hline \multirow{2}{*}{ Karakteristik pemasakan } & \multicolumn{4}{c}{ Suhu $\left({ }^{\circ} \mathrm{C}\right)$} \\
\cline { 2 - 5 } & 150 & 160 & 170 & 180 \\
\hline & 1,32 & 1,30 & 1,28 & 1,41 \\
$M_{\mathrm{H}}(\mathrm{kg}-\mathrm{cm})$ & 0,17 & 0,17 & 0,15 & 0,18 \\
$M_{\mathrm{L}}(\mathrm{kg}-\mathrm{cm})$ & 1,15 & 1,13 & 1,13 & 1,23 \\
$M_{\mathrm{H}}-M_{\mathrm{L}}(\mathrm{kg}-\mathrm{cm})$ & 8,40 & 5,31 & 3,37 & 2,13 \\
$\mathrm{t}_{90}($ menit $)$ & & & NBR 28 & \\
\hline & 1,34 & 1,36 & 1,32 & 1,29 \\
$M_{\mathrm{H}}(\mathrm{kg}-\mathrm{cm})$ & 0,10 & 0,10 & 0,19 & 0,14 \\
$M_{\mathrm{L}}(\mathrm{kg}-\mathrm{cm})$ & 1,24 & 1,26 & 1,13 & 1,15 \\
$M_{\mathrm{H}}-M_{\mathrm{L}}(\mathrm{kg}-\mathrm{cm})$ & 8,38 & 4,56 & 3,16 & 2,11 \\
$\mathrm{t}_{90}($ menit $)$ & & & NBR 33 & \\
& 1,25 & 1,25 & 1,20 & 1,17 \\
$M_{\mathrm{H}}(\mathrm{kg}-\mathrm{cm})$ & 0,12 & 0,14 & 0,16 & 0,21 \\
$M_{\mathrm{L}}(\mathrm{kg}-\mathrm{cm})$ & 1,13 & 1,11 & 1,04 & 0,96 \\
$M_{\mathrm{H}}-M_{\mathrm{L}}(\mathrm{kg}-\mathrm{cm})$ & 8,16 & 5,20 & 3,15 & 2,17 \\
$\mathrm{t}_{90}($ menit $)$ & & &
\end{tabular}


komponnya, atau dengan kata lain peningkatan suhu vulkanisasi dapat mempercepat waktu pematangan kompon. Perbedaan kandungan akrilonitril karet NBR menghasilkan waktu vulkanisasi yang relatif sama. Optimum curing time menunjukkan konversi energi selama proses vulkanisasi karet NBR (Chandrasekara et al., 2011). Tabel 2 menunjukkan bahwa konversi energi NBR 33 selama proses vulkanisasi sedikit rendah dibanding kompon lainnya. Kerapatan ikatan silang yang terbentuk pada NBR 33 lebih kecil dibandingkan NBR 26 dan NBR 28, maka tenaga yang dibutuhkan selama pemasakan akan lebih sedikit dibandingkan karet NBR yang memiliki kerapatan ikatan silang yang besar.

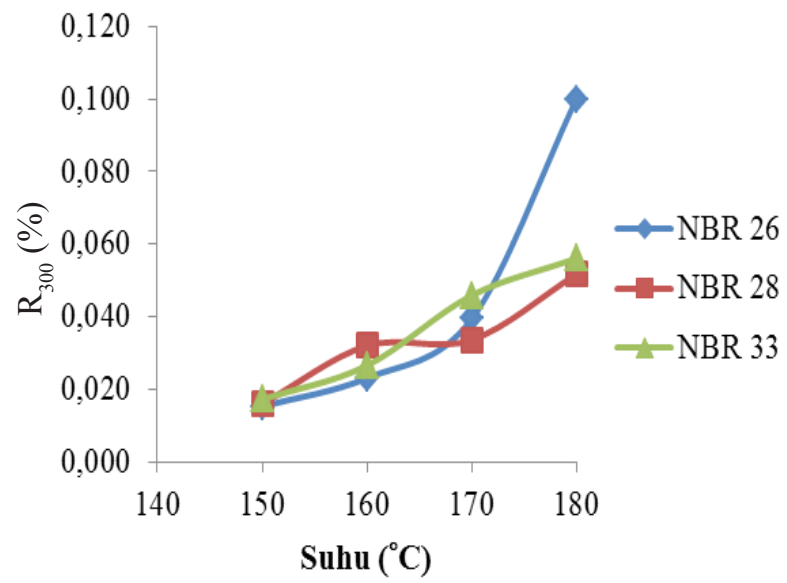

Gambar 1. $\mathrm{R}_{300}$ kompon karet NBR.
Peningkatan suhu vulkanisasi berpengaruh terhadap penurunan torsi setelah torsi maksimum $\left(\mathrm{R}_{300}\right)$ (Gambar 1). Peningkatkan suhu vulkanisasi menyebabkan kenaikan $\mathrm{R}_{300}$. Hasil ini sesuai dengan Khan \& Ariff (2011), dimana vulkanisat karet alam yang diuji mengalami penurunan pemasakan seiring kenaikan suhu pemasakan. Kompon NBR dengan kandungan akrilonitril rendah $(26 \% \mathrm{~b} / \mathrm{b})$ pada suhu $180^{\circ} \mathrm{C}$ mengalami kenaikan $\mathrm{R}_{300}$ yang lebih tinggi dibanding kompon lainnya. Peningkatan kandungan akrilonitril cenderung menurunkan $\mathrm{R}_{300}$. Peningkatan $\mathrm{R}_{300}$ disebabkan karena terjadinya pemutusan ikatan silang hasil reaksi vulkanisasi. Pada kompon dengan kandungan akrilonitril tinggi (33\%), ikatan silang relatif sedikit, ditunjukkan dengan nilai torsi maksimum yang relatif lebih kecil.

\section{Karakteristik Pematangan Karet Alam}

Hasil pengamatan karakteristik pemasakan kompon karet alam menunjukkan bahwa suhu vulkanisasi menaikkan torsi maksimum, minimum dan delta torsi pada masing-masing sistem vulkanisasi (Tabel 3). Sistem vulkanisasi SEV memiliki nilai delta torsi yang lebih besar dibandingkan dengan sistem EV dan donor sulfur. Hal ini menunjukkan bahwa ikatan silang yang terbentuk pada sistem ini lebih banyak dibandingkan sistem EV dan donor sulfur. Perbandingan jumlah sulfur dan pencepat pada sistem vulkanisasi

Tabel 3. Karakteristik pemasakan kompon karet alam.

\begin{tabular}{|c|c|c|c|c|}
\hline \multirow{2}{*}{ Karakteristik pemasakan } & \multicolumn{4}{|c|}{ Suhu $\left({ }^{\circ} \mathrm{C}\right)$} \\
\hline & 150 & 160 & 170 & 180 \\
\hline & \multicolumn{4}{|c|}{ Kompon NRSEV } \\
\hline$M_{\mathrm{H}}(\mathrm{kg}-\mathrm{cm})$ & 2,22 & 2,72 & 2,65 & 2,60 \\
\hline$M_{\mathrm{L}}(\mathrm{kg}-\mathrm{cm})$ & 0,24 & 0,29 & 0,30 & 0,31 \\
\hline$M_{\mathrm{H}}-M_{\mathrm{L}}(\mathrm{kg}-\mathrm{cm})$ & 1,98 & 2,43 & 2,35 & 2,29 \\
\hline \multirow[t]{2}{*}{$\mathrm{t}_{90}$ (menit) } & 7,15 & 4,33 & 2,45 & 1,50 \\
\hline & \multicolumn{4}{|c|}{ Kompon NREV } \\
\hline$M_{\mathrm{H}}(\mathrm{kg}-\mathrm{cm})$ & 1,44 & 1,42 & 1,77 & 1,61 \\
\hline$M_{\mathrm{L}}(\mathrm{kg}-\mathrm{cm})$ & 0,15 & 0,22 & 0,24 & 0,21 \\
\hline$M_{\mathrm{H}}-M_{\mathrm{L}}(\mathrm{kg}-\mathrm{cm})$ & 1,29 & 1,20 & 1,53 & 1,40 \\
\hline \multirow[t]{2}{*}{$\mathrm{t}_{90}$ (menit) } & 11,50 & 7,02 & 3,50 & 2,20 \\
\hline & \multicolumn{4}{|c|}{ Kompon NRDonor } \\
\hline$M_{\mathrm{H}}(\mathrm{kg}-\mathrm{cm})$ & 1,16 & 1,16 & 1,06 & 1,16 \\
\hline$M_{\mathrm{L}}(\mathrm{kg}-\mathrm{cm})$ & 0,18 & 0,23 & 0,16 & 0,17 \\
\hline$M_{\mathrm{H}}-M_{\mathrm{L}}(\mathrm{kg}-\mathrm{cm})$ & 0,98 & 0,93 & 0,90 & 0,99 \\
\hline $\mathrm{t}_{90}$ (menit) & 20,16 & 11,15 & 6,30 & 3,45 \\
\hline
\end{tabular}


SEV lebih besar dibandingkan EV, sehingga pada sistem SEV lebih banyak terbentukmya ikatan silang polisulfida $\left(C-\mathrm{S}_{\mathrm{x}}-\mathrm{C}\right)$ dan disulfida (C-S$\mathrm{S}-\mathrm{C}$ ) dibandingkan monosulfida (C-S-C) (Hofmann, 1965; Fan et al., 2001; Nocil Ltd, 2010). Pada sistem vulkanisasi donor sulfur (NRDonor), digunakan DTDM sebagai agen vulkanisasinya sebagai pengganti sulfur. Pada sistem ini hanya terbentuk ikatan disulfida (C-S-S-C) (Posadas et al., 2010), sehingga sistem ini memiliki jumlah ikatan silang paling kecil dibandingkan sistem SEV (NRSEV) dan sistem EV (NREV). Jika dibandingkan dengan karakteristik pematangan karet NBR (Tabel 2), karet alam memiliki nilai delta torsi yang relatif lebih besar. Hal ini mengindikasikan bahwa karet alam membentuk ikatan silang yang lebih banyak dibandingkan karet sintetik (NBR). Hofmann (1965) menjelaskan bahwa karet alam memiliki ikatan rangkap yang lebih banyak dibandingkan karet sintetis, sehingga karet alam akan lebih banyak menghasilkan ikatan silang ketika bereaksi dengan sulfur.

Waktu pematangan $\left(\mathrm{t}_{90}\right)$ karet alam semakin singkat seiring kenaikan suhu vulkanisasi. Waktu pematangan sistem SEV lebih singkat dibandingkan sistem EV dan donor sulfur. Hal ini dipengaruhi oleh jumlah ikatan silang yang terbentuk pada masing-masing sistem. Hofmann (1965), menjelaskan semakin banyaknya ikatan silang yang terbentuk maka semakin cepat waktu vulkanisasinya. Pada sistem SEV ikatan silang yang terbentuk paling banyak dibandingkan sistem EV dan donor sulfur. Oleh karena itu sistem SEV paling cepat waktu pematangannya. Dibandingkan dengan karet NBR, karet alam pada sistem SEV memiliki waktu pematangan yang relatif lebih singkat dibandingkan karet NBR. Hal ini dimung-

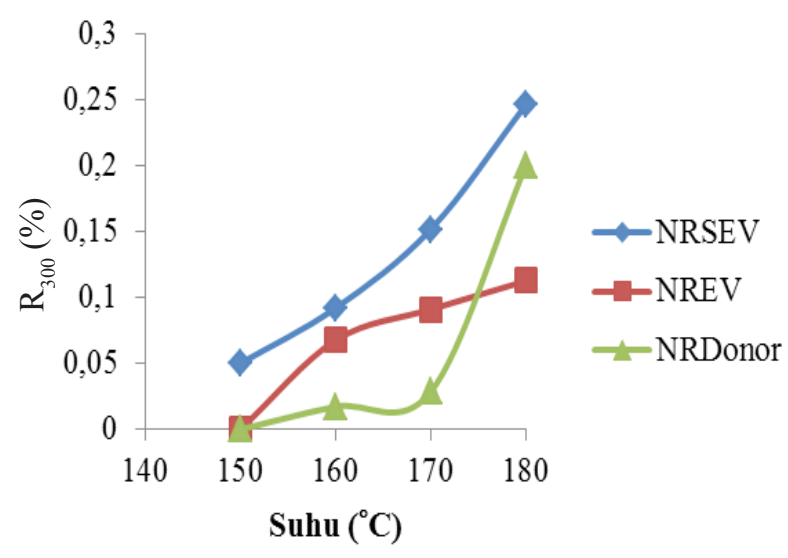

Gambar 2. $\mathrm{R}_{300}$ kompon karet alam. kinkan karena jumlah ikatan silang yang terbentuk pada kompon NRSEV lebih besar dibandingkan kompon NBR. Selain itu, karet alam yang terbentuk dari lateks (yang tersusun dari albumin, produk dekomposisi albumin, amin) turut mempercepat vulkanisasi (Altman, 1948), sedangkan sebagian besar karet sintetis terdiri dari beberapa resin atau asam lemak sisa dari proses polimerisasi yang dapat menghambat vulkanisasi (Hofmann, 1965). Namun, waktu pematangan pada sistem EV dan donor sulfur lebih lama dibandingkan karet NBR meskipun jumlah ikatan silang kompon NREVdan NRDonor lebih besar dari kompon NBR. Hal ini mungkin disebabkan oleh jumlah sulfur yang digunakan lebih sedikit dan pencepat yang ditambahkan pada kompon NBR yang lebih besar dari pada kompon NREV dan NRDonor (Tabel 1), sehingga waktu vulkanisasi berjalan lebih cepat.

Pada ketiga kompon karet alam terjadi penurunan torsi setelah tercapainya torsi maksimum (Gambar 2). Vulkanisat karet alam mengalami kenaikan $\mathrm{R}_{300}$ seiring peningkatkan suhu vulkanisasi. Pada masing-masing suhu vulkanisasi dapat diketahui bahwa kompon NRSEV mengalami penurunan torsi terbesar. Karet alam yang divulkanisasi dengan sistem SEV (NRSEV) membentuk ikatan silang polisulfida yang lebih banyak dibandingkan pada sistem EV (NREV), dimana ikatan silang jenis polisulfida cenderung mengalami penurunan torsi terbesar (Fan et al., 2001). Ikatan silang jenis polisulfida (C-S $-\mathrm{C})$ yang terbentuk pada sistem SEV memiliki kekuatan ikatan silang $<64 \mathrm{kkal} / \mathrm{mol}$, lebih kecil dibandingkan kekuatan ikatan monosulfida (C-S-C) sebesar 68 $\mathrm{kkal} / \mathrm{mol}$ dan ikatan C-C sebesar $84 \mathrm{kkal} / \mathrm{mol}$ (Landod-Börnstein, 1936). Selain itu, ikatan silang C-S $-\mathrm{C}$ memiliki sifat tidak stabil terhadap panas (Hofmann, 1965). Kekuatan ikatan yang rendah antar ikatan silang dan sifat polisulfida yang rentan terhadap suhu menyebabkan penurunan torsi yang relatif besar pada vulkanisat yang divulkanisasi dengan sistem SEV (NRSEV).

\section{Sifat Mekanis Karet NBR}

Sifat mekanis karet NBR sangat dipengaruhi oleh kandungan akriloniril karet NBR dan suhu vulkanisasinya (Gambar 3). Keelastisan karet ditentukan oleh nilai kekerasan, kuat tarik, perpanjangan putus dan pampat tetap elastomer tersebut, dimana keempatnya dipengaruhi oleh ikatan silang yang terbentuk di molekul-molekul karet. Hammed (2012) menjelaskan bahwa ketika suatu elastomer yang tidak berikatan silang (uncross- 


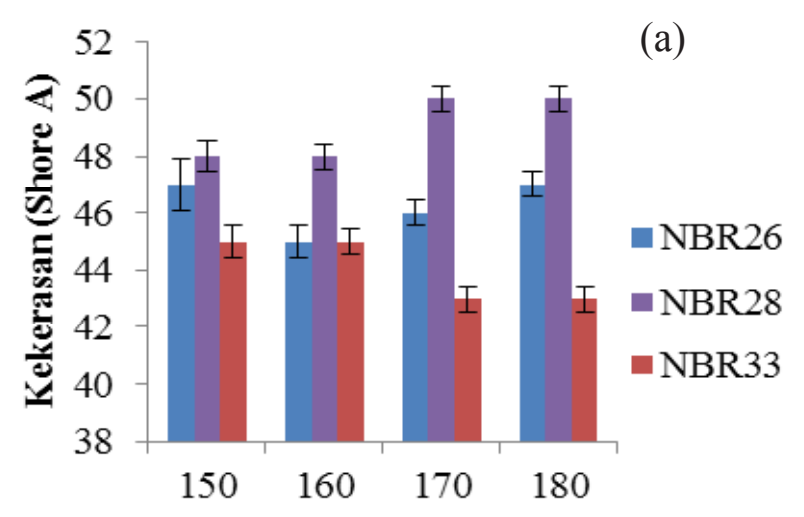

Suhu vulkanisasi $\left({ }^{\circ} \mathrm{C}\right)$

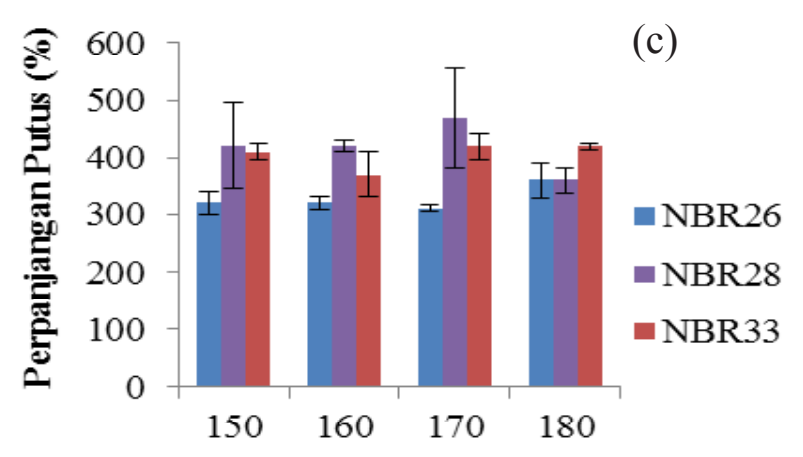

Suhu vulkanisasi $\left({ }^{\circ} \mathrm{C}\right)$
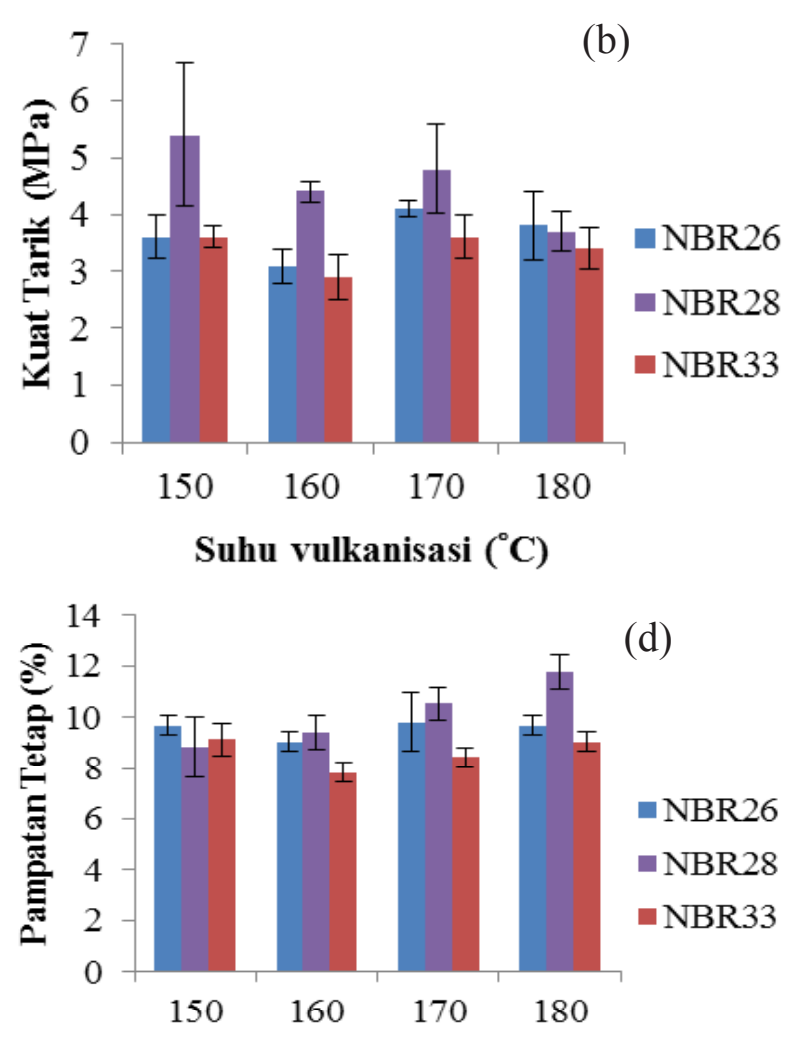

Suhu vulkanisasi $\left({ }^{\circ} \mathrm{C}\right)$

Gambar 3. (a) Kekerasan, (b) kuat tarik, (c) perpanjangan putus, dan (d) pampatan tetap vulkanisat karet NBR pada berbagai kandungan akrilonitril dan suhu vulkanisasi.

linked) diberi suatu tekanan, maka rantai-rantai molekulnya lebih mudah mengalir dan mengurai. Sedangkan pada elastomer yang berikatan silang (crosslinked) terjadi kenaikan berat molekul, percabangan molekul dan distribusi berat molekul yang meluas. Sehingga, ketika diberi tekanan, maka diperlukan kekuatan yang lebih besar untuk memecahkan ikatan kimia dan membuat permukaannya retak. Maka, peningkatan nilai kuat tarik dan perpanjangan putus menunjukkan bahwa vulkanisat karet NBR semakin elastis.

Kekerasan, kuat tarik, perpanjangan putus, dan pampat tetap vulkanisat karet NBR meningkat seiring meningkatnya kandungan akrilonitrilnya (Yasin et al., 2003; Lachat, 2008; Dick \& Rader, 2014). Namun, kenaikan kekerasan, kuat tarik, perpanjangan putus, dan pampat tetap vulkanisat karet NBR hanya terjadi hingga kandungan akrilonitril 28\% (b/b), kemudian menurun pada NBR dengan kandungan akrilonitril 33\% (b/b). Sifat mekanis vulkanisat karet NBR dipengaruhi oleh kerapatan ikatan silangnya. Nilai ini sebanding dengan hasil pengamatan karakteristik pemasakannya (Tabel 2), dimana delta torsi kompon NBR meningkat hingga kandungan akrilonitril 28\%, kemudian mengalami penurunan pada NBR dengan kandungan akrilonitril 33\%.

Kenaikan suhu vulkanisasi turut mempengaruhi kekerasan, kuat tarik, perpanjangan putus, dan pampat tetap vulkanisat karet NBR. Vulkanisat karet NBR menunjukkan mengalami penurunan kekerasan, kuat tarik, perpanjangan putus dan pampat tetap ketika suhu vulkanisasi naik dari $150^{\circ} \mathrm{C}$ menjadi $160^{\circ} \mathrm{C}$. Namun, kemudian nilai kekerasan kuat tarik, perpanjangan putus dan pampat tetap meningkat ketika suhu vulkanisasi naik dari $160^{\circ} \mathrm{C}$ menjadi $170^{\circ} \mathrm{C}$. Keelastisan suatu elastomer diketahui ketika nilai kekerasan dan pampat tetap elastomer tersebut kecil. Gambar 3a dan 3d menunjukkan bahwa vulkanisat NBR dengan kandungan akrilonitril rendah mencapai nilai kekerasan dan pampat tetap rendah ketika divulkanisasi pada suhu $150^{\circ} \mathrm{C}$, sedangkan vulkanisat NBR dengan kandungan akrilonitril tinggi mencapai nilai kuat tarik dan pampat tetap yang lebih baik ketika divulkanisasi pada suhu $170^{\circ} \mathrm{C}$. Hasil ini menunjukkan bahwa karet NBR dengan kandungan akrilonitril rendah lebih sesuai jika divul- 
kanisasi pada suhu rendah, sedangkan karet NBR dengan kandungan akrilonitril besar lebih sesuai jika divulkanisasi dengan suhu tinggi.

\section{Sifat Mekanis Karet Alam}

Sifat mekanis karet alam sangat dipengaruhi oleh ikatan silang yang terbentuk dari masingmasing sistem vulkanisasi. Sifat mekanis karet alam yang dihasilkan dari variasi sistem dan suhu vulkanisasi disajikan pada Gambar 4. Kekerasan dan kuat tarik pada masing-masing suhu vulkanisasi menunjukkan bahwa sistem vulkanisasi $\mathrm{SEV}>\mathrm{EV}>$ donor sulfur. Hal ini dikarenakan jumlah ikatan silang yang ditunjukkan oleh nilai $M_{\mathrm{H}}$ pada sistem vulkanisai $\mathrm{SEV}>\mathrm{EV}>$ donor belerang (Tabel 3). Pada sistem SEV terdapat ikatan polisulfida $\left(\mathrm{C}-\mathrm{S}_{\mathrm{x}}-\mathrm{C}\right)$ yang lebih banyak dibandingkan pada sistem vulkanisasi EV dan donor sulfur, ikatan ini memiliki karakteristik kekerasan dan kuat tarik yang baik (Hofmann, 1965). Hasil penelitian Gonzalez et al. (2005) menyatakan bahwa semakin besar ikatan silang yang terbentuk pada karet alam, maka semakin besar pula kekuatan tariknya.
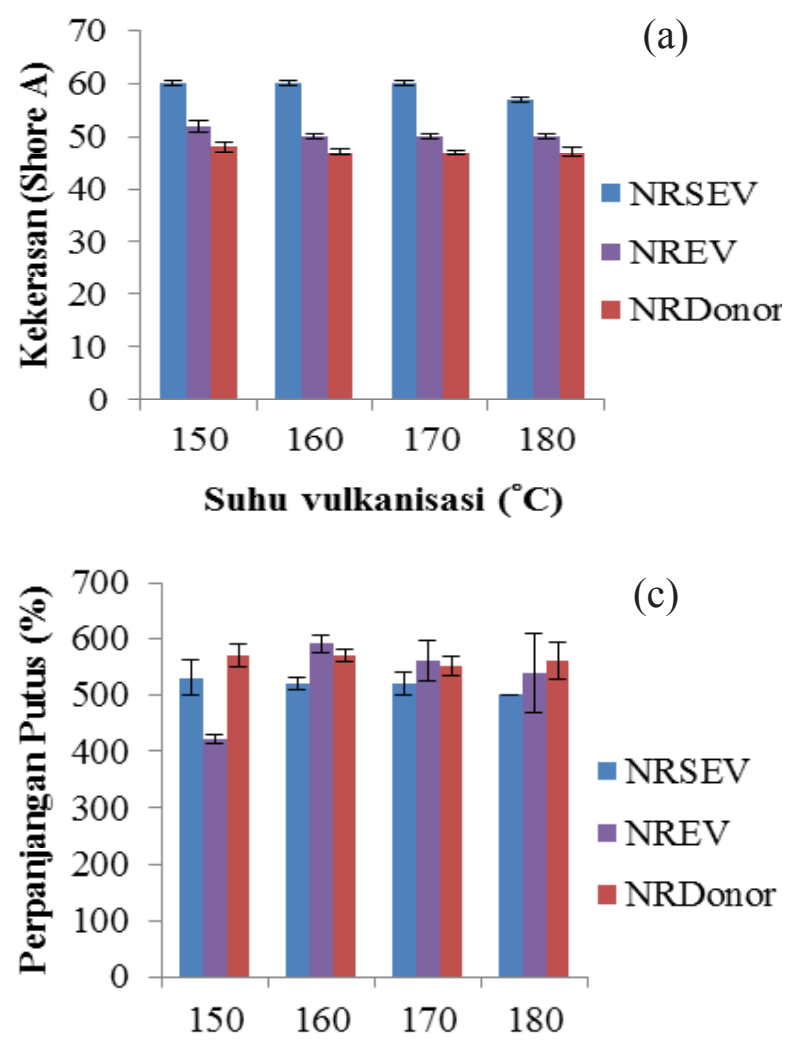

Suhu vulkanisasi $\left({ }^{\circ} \mathrm{C}\right)$
Gambar 4(a) dan 4(b) menunjukkan bahwa kekerasan dan kuat tarik vulkanisat karet alam menurun seiring kenaikan suhu vulkanisasinya. Hasil menunjukkan bahwa ketika divulkanisasi pada suhu tinggi karet alam menujukkan sifat kekerasan yang semakin baik, namun sifat kuat tariknya semakin menurun, baik dengan sistem vulkanisasi EV, SEV ataupun donor sulfur. Jika dibandingkan dengan karet NBR, karet alam memiliki kekerasan dan kuat tarik vulkanisat yang lebih besar. Nilai kekerasan NR yag lebih besar dari NBR dipengaruhi oleh jumlah ikatan silang pada karet alam yang lebih besar dibandingkan karet NBR, nilai ini ditunjukkan dari besarnya nilai delta torsi NR (Tabel 2 dan Tabel 3). Nilai kekuatan tarik yang lebih besar menunjukkan bahwa NR lebih elastis dibandingkan NBR.

Perpanjangan putus pada sistem SEV, EV dan donor sulfur menunjukkan kecenderungan bahwa perpanjangan putus karet berbanding terbalik dengan kekerasan karetnya. Perpanjangan putus vulkanisat karet alam meningkat seiring kenaikan suhu vulkanisasinya (Gambar 4(c)), sedangkan kekerasan karet alam menurun seiring kenaikan
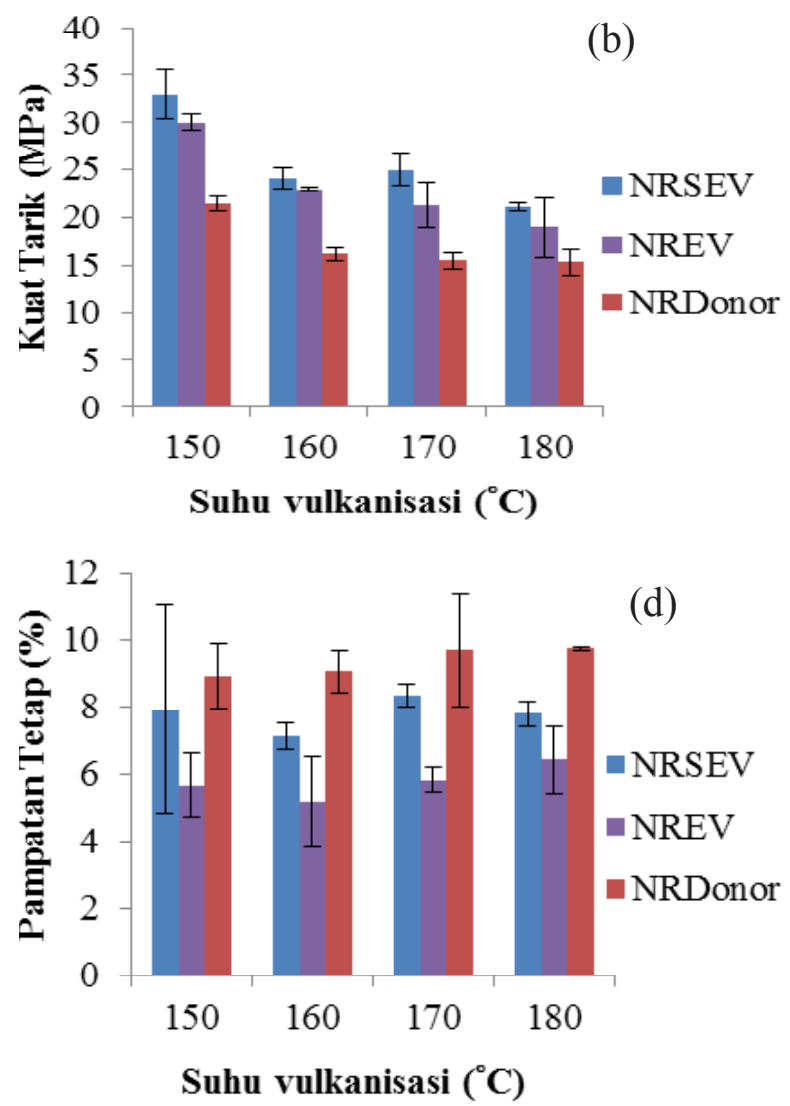

Gambar 4. (a) Kekerasan, (b) kuat tarik, (c) perpanjangan putus, dan (d) pampatan tetap vulkanisat karet NR pada berbagai sistem dan suhu vulkanisasi. 
suhunya (Gambar 4(b)). Semakin tinggi kekerasan suatu karet, maka jumlah ikatan silang di antara rantai polimernya semakin banyak dan semakin tidak mudah untuk bergerak, sehingga menyebabkan perpanjangan putusnya menurun (Yasin et al., 2003). Dengan demikian, semakin elastisnya suatu karet (kekerasan kecil), maka akan semakin besar nilai perpanjangan putusnya. Perpanjangan putus yang dihasilkan oleh vulkanisat karet alam memiliki nilai yang lebih besar dibandingkan karet NBR (Gambar 3(c)), hal ini menunjukkan bahwa NR lebih elastis dibandingkan karet NBR.

Hasil pampat tetap karet alam dipengaruhi oleh sistem dan suhu vulkanisasi. Sistem vulkanisasi EV menghasilkan pampat tetap terendah dibandingkan kedua sistem vulkanisasi. Jenis ikatan silang yang terbentuk pada sistem EV didominasi oleh ikatan monosulfida, yang memiliki sifat pampat tetap yang rendah (Hofmann, 1965; Nocil Ltd, 2010). Pampat tetap masing-masing sistem vulkanisasi meningkat seiring kenaikan suhu vulkanisasi. Peningkatan nilai pampat tetap menunjukkan bahwa karet tidak elastis. Namun jika dibandingkan dengan nilai pampat tetap karet NBR, karet alam memiliki nilai pampat tetap yang relatif lebih kecil. Hal ini menunjukkan bahwa karet alam memiliki elasitas yang lebih baik dibanding karet NBR.

\section{KESIMPULAN}

Hasil pengamatan pengaruh suhu vulkanisasi pada karet NBR dengan kandungan akrilonitril yang berbeda $(26 \%, 28 \%$ dan $33 \%)$ menunjukkan bahwa karet NBR dengan kandungan akrilonitril rendah memiliki karakteristik pematangan dan sifat mekanis yang lebih baik saat divulkanisasi pada suhu rendah $\left(150^{\circ} \mathrm{C}\right)$, sedangkan karet NBR dengan kandungan akrilonitril yang tinggi memiliki karakteristik pematangan dan sifat mekanis yang lebih baik saat divulkanisasi pada suhu tinggi $\left(170^{\circ} \mathrm{C}\right)$. Sedangkan hasil pengamatan pada vulkanisat karet alam yang divulkanisasi dengan sistem pematangan yang berbeda (SEV, EV, dan donor sulfur) pada suhu vulkanisasi yang berbeda $\left(150,160,170\right.$, dan $\left.180^{\circ} \mathrm{C}\right)$ menunjukkan bahwa karet alam lebih sesuai divulkanisasi menggunakan sistem vulkanisasi SEV dengan suhu vulkanisasi sebesar $150^{\circ} \mathrm{C}$.

\section{UCAPAN TERIMA KASIH}

Ucapan terima kasih disampaikan kepada Kemenristek Dikti atas bantuan dana Sinas 2015 sehingga dapat terlaksananya penelitian ini. Penulis turut menghaturkan ucapan terimakasih kepada Pusat Penelitian Karet khususnya kepada Dr. Dadi Maspanger atas bimbingannya dalam penyusunan naskah publikasi. Ucapan terimakasih disampaikan pula kepada teknisi penelitian (Yati Nurhayati,S. Si dan Woro Andriani,S.Si) dan teknisi laboratorium pengujian fisika dan pabrik percobaan (Anwar Tavip, Muchtar, dan Jaenal, ST) atas masukan dan bantuannya dalam penelitian ini.

\section{DAFTAR PUSTAKA}

Altman, R. F. A. (1948). Natural vulcanization accelerators in Hevea latex. Industrial \& Engineering Chemistry, 40(2), 241-249.

Basfar, A. A., Abdel-Aziz, M. M., \& Mofti, S. (2002). Influence of different curing systems on the physico-mechanical properties and stability of SBR and NR rubbers. Radiation Physics and Chemistry, 63, 81-87.

Bhowmick, A. K., \& De, S. K. (1979). Effect of curing temperature on the technical properties of nitrile rubber and carboxylated. Rubber Chemistry and Technology, 53, 107-115.

Blokh, G. A. (1972). Organic accelerators in the vulcanization of rubber (2nd ed.). Leningrad, USSR: Khimia.

Brydson, J. A. (1988). Rubbery materials and their compounds. Amsterdam, Netherlands: Elsevier Applied Science.

Chandrasekara, G., Mahanama, M. K., Edirisinghe, D. G., \& Karunayake, L. (2011). Epoxidized vegetable oils as processing aid activators in carbon-black filled natural rubber compounds. Journal of National Science Foundation of Srilangka, 39(3), 244-250.

Chasar, D. W., \& Layer, R. W. (1996). Basic rubber compounding. In R. F. Ohm (ed.). The Vanderbilt rubber handbook (13th ed., pp. 10-22). New York, USA: R. T. Vanderbilt Company, Inc.

Dick, J. S., \& Rader C. P. (2014). Raw materials supply chain for rubber products: overview of the global use of raw materials, polymers, compounding ingredients, and chemical intermediates. Munich, Germany: Hanser Publishers.

El-Nemr, K. F. (2011). Effect of different curing systems on the mechanical and physico-chemical properties of acrylonitrile butadiene rubber vulcanizates. Materials and Design, 32, 3361-3369.

Fan, R. L., Zhang, Y., Li, F., Zhang, Y. X., Sun, K., \& Fan, Y. Z. (2001). Effect of high-temperature curing on the crosslink structures and dynamic mechanical properties of gum and N330-filled natural rubber vulcanizates. Polymer Testing, 20(8), 925-936.

Gonzalez, L., Rodriguez, A., Del Campo, A., \& 
Marcos-Fernandez, A. (2002). Crosslink reaction of natural rubber with thiuram sulphur donors in the presence of a thiuram monosulfide. Journal of Applied Polymer Science, 85, 491-499.

Gonzalez, L., Rodriguez, A., Valentın, J. L., MarcosFernandez, A., \& Posadas, P. (2005). Conventional and efficient crosslinking of natural rubber, effect of heterogeneities on the physical properties. Kautschuk und Gummi Kunststoffe, 58(12), 638643.

Hamed, G. R. (2012). Material and compound. In A. N. Gent (ed). Engineering with rubber: How to design rubber components (3rd ed). Munich, Germany: Carl Hanser Verlag.

Hofmann, W. (1965). Vulcanization and vulcanizing agent. Leverkusen, Jerman: The Mclaren Group.

Indra, S., Ismail, H., \& Azura, A.R., (2013). Alkanolamide as an accelerator, fller-dispersant and a plasticizer in silica-flled natural rubber compound. Polymer Testing, 32(8), 1313-1321.

Indrajati, I. N., \& Sholeh, M. (2014). Pengaruh rasio MBTS/ZDEC pada campuran karet alam dan etilen propilen diena yang dibuat dengan teknik kontrol migrasi curatives. Majalah Kulit, Karet, dan Plastik, 30(1), 43-52.

Khang, T. H., \& Ariff, Z. M. (2011). Vulcanization kinetics study of natural rubber compounds having different formulation variables. Journal of Thermal Analysis and Calorimetry, 109, 1545-1553.

Konar, B. B., \& Saha, M. (2012). Infuence of polymer coated $\mathrm{CaCO}_{3}$ on vulcanization kinetic of natural rubber/sulfur/N-oxydiethyl benzthiazyl sulfenamide (BSM) system. Journal of Macromolecul Science Part A: Pure Applied Chemistry, 49, 214-226.

Lachat, V. (2008). Understanding oil resistance of nitrile rubber: $C N$ group interactions at interfaces. (Dissertation). The University of Akron, USA.

Landod-Börnstein. (1936). Physikhalisch-chemische Tabellen. Third supplement book: Book 3 (5th ed). Berlin, Germany: Julius Springer-Verlag.

Long, H. (1985). Basic compounding and processing of rubber. New Jersey, USA: American Chemical Society.

Marković, G., Marinović-Cincović, M., Jovanović, V., Samaržija-Jovanović, S., \& Budinski-Simendić. (2013). NR/CSM/biogenic silica rubber blend composites. Composites Part B: Engineering, 55, 368-373.

Mukhopadhyay R., De, S. K., \& Chakraborty, S. N. (1977). Effect of vulcanization temperature and vulcanization systems on the structure and properties of natural rubber vulcanizates. Polymer, $18,1243-1249$
Nabil, H., Ismail, H., \& Azura, A. R. (2013). Compounding, mechanical and morphological properties of carbon-black-fller natural rubber/ recycled ethylene - propylene - diene - monomer blends, Polymer Testing, 32, 385-393.

Nabil, H., Ismail, H., \& Azura, A. R. (2013a). Effect of virgin ethylene-propylene-diene-monomer and its preheating time on the properties of natural rubber/ recycled ethylene - propylene - diene - monomer blends. Material and Design, 50, 27-37.

Nocil Ltd. (2010). Vulcanization \& Accelerators. India: Arvind Marfatlad Group.

Pal, P. K., Bhowmick, A. K., \& De, S. K. (1981). The effects of carbon black-vulcanization system interactions on natural rubber network structures and properties. Rubber Chemistry and Technology, $55,23-55$.

Palaty, S. (2002). New accelerator system for low temperature curing of elastomers with special reference to $N R, N B R$ and $N R / B R$ blends (Disssertation), Cochin University of Science and Technology, India.

Palaty, S., \& Joseph, R. (2001). Studies on xanthate-zinc diethyl dithiocarbamate accelerator combination in natural rubber. Plastics Rubber and Composites, 30(6), 270-274.

Palaty,S. \& Joseph, R. (2006). Low temperature curing of NBR for property improvement. Journal of Elastomers and Plastics, 38(3), 199-209.

Posadas, P., Fernandez-Torres, A., Valentın, J. L., Rodriguez, A., \& Gonzalez, L. (2010). Effect of the temperature on the kinetic of natural rubber vulcanization with the sulfur donor agent dipentamethylene thiuram tetrasulphide. Journal of Applied Polymer Science, 115, 692-701.

Yasin, T., Ahmed, S., Yoshii, F., \& Makuuchi, K. (2003). Effect of acrylonitrile content on physical properties of electron beam irradiated acrylonitrile-butadiene rubber. Reactive \& Functional Polymers, 57, 113-118.

Zhang, H., Li, Y., Shou, J., Zhang, Z., Zhao, G., \& Liu, Y. (2015). Effect of curing temperature on properties of semi-efficient vulcanized natural rubber. Journal of Elastomer and Plastic. doi: 10.1177/0095244315576243. 